\title{
The Role of Quality of Work Life as a Predictor of Counterproductive Work Behavior
}

\author{
P. Tommy Y. S. Suyasa \\ Faculty of Psychology Universitas Tarumanagara
}

\begin{abstract}
Counterproductive work behavior (CWB) is work behavior that violates the rules/norms (written or unwritten) that could potentially harm an organization or members of an organization. This study aimed to explain CWB based on the condition of the quality of work life (QWL). CWB can be negative behavior towards co-workers/supervisors/subordinates in the workplace (CWB-I) and can be either negative behavior towards tasks/rules/organizational system (CWB-O). Participants in this study were the members of National Police. The number of participants was 305 people. Based on the analysis, the better the quality of relationships with supervisors (supervisory), the implementation of work culture (constitutionalism), the quality of relationships with co-workers (co-worker), and the quality of tasks/ responsibilities (promotion), the lower the CWB-I. Meanwhile, the lower levels of CWB-O were predicted by the promotion of quality of relationships with supervisors (supervisory). The study raised a further question concerning why the higher quality of/balance between work and private life (work life balance) led into the higher levels of CWB-I.
\end{abstract}

Keywords: counterproductive work behavior, interpersonal behavior, organizational system, quality of work life, supervisory

Counterproductive work behavior (CWB) adalah perilaku kerja yang melanggar aturan/norma (baik tertulis maupun tidak tertulis) yang berpotensi merugikan organisasi atau anggota organisasi. Penelitian ini bertujuan untuk menjelaskan CWB berdasarkan kondisi quality of work life (QWL). CWB dapat berupa perilaku negatif terhadap rekan/atasan/bawahan di tempat kerja (CWB-I) dan dapat berupa perilaku negatif terhadap tugas/aturan/sistem organisasi (CWB-O). Partisipan pada penelitian ini $(N=305)$ adalah anggota Kepolisian. Berdasarkan hasil analisis, semakin baik kualitas hubungan dengan atasan (supervisory), penerapan budaya kerja (constitutionalism), peningkatan kualitas hubungan dengan rekan kerja (coworker), dan peningkatan kualitas tugas/jawab (promotion), maka semakin rendah CWB-I. Adapun rendahnya CWB-O, dapat diprediksi melalui kondisi peningkatan kualitas hubungan dengan atasan (supervisory). Penelitian ini menimbulkan pertanyaan lebih lanjut, mengapa semakin tinggi kualitas/keseimbangan antara pekerjaan dan kehidupan pribadi (work life balance), justru semakin tinggi CWB-I.

Kata kunci: perilaku kerja counterproductive, interpersonal, sistem organisasi, kualitas kerja dan kehidupan, supervisi

The vision of the Indonesian National Police (POLRI) is being able to be the protector and servant of the community who is closely tied to and works together with the community, as well as being able to be the professional and appropriate law enforcer who always upholds the supremacy of internal security in a democratic national life and a prosperous society (Kepolisian Republik Indonesia, n.d.).

Correspondence concerning this article should be addressed to $\mathrm{P}$. Tommy Y. S. Suyasa, Faculty of Psychology Universitas Tarumanagara. Jalan Letjen S. Parman No. 1, Tomang, Grogol Petamburan, Kota Jakarta Barat Daerah Khusus Ibukota Jakarta 11440; E-mail: tommys $@$ @psi.untar.ac.id
Considering the independence, authority, and importance of POLRI's duties, the POLRI is directly responsible under the President. One of the three main duties of POLRI is to enforce the law (Undang-Undang Republik Indonesia Number 2 Year 2002 on Indonesian National Police, Article 5 Paragraph 1). Nevertheless, the POLRI that should enforce the law, is instead considered as the top three institutions that receives the most complaints from the public regarding the violation (law/rule) in the execution of their duties.

General Sutarman, the Chief of the Indonesian Na- 
tional Police (October 25, 2013 - January 16, 2015), stated that the number of sanctions or punishments for Indonesian Police personnel who committed violations has have increased in 2014 compared to that in 2013. During 2014, a total of 9,892 police personnel violated the law; while the number of sanctions given to the POLRI personnel who violated the law in 2013 were 4,315.

Sanctions given to the POLRI members who committed disciplinary violations have increased by $129.2 \%$ (Munir, 2014). In addition, based on the reports of public complaints through the Ombudsman institution, the police force was one of the institutions that had the 3rd (third) highest number of reported violations. The local government had 2,329 reports $(45.02 \%)$, the police had 668 reports $(12.91 \%)$, and government Ministries had 520 reports (10.05\%).

This phenomenon indicates that the police who should have been the enforcer of discipline and rules, have instead become the violators of the rules. In Government Regulation Number 2 of the year 2003 regarding the obligation and prohibition against the members of police, it was stated that the members of POLRI are obligated to comply with the prevailing legislation concerning official duties and general duties and to behave politely in the community. They are also prohibited from doing things that damage the reputation of the Indonesian National Police.

The POLRI members who show inappropriate behavior as described in the rules above are considered showing counterproductive work behavior (CWB; Marcus \& Schuler, 2004; Sackett, 2002). CWB is indicated by a numerous behaviors that are not in alignment with the goal/interest of an organization; and are illegitimate; or is indicated by behaviors that violate the rules/norms, or show deviant workplace behaviors (Robinson \& Bennett, 1995).

Despite the increased violations of discipline by POLRI members, there have been limited studies that explain various (potential) types of violations under the concept of CWB. Jacobs, Belschak, and Hartog (2014) have conducted CWB research among the members of police force. Jacobs et al. (2014) stated that perceived supervisor and organizational support are the mediators between justice perceptions and CWB (unethical work behavior) in the police force. That is, participants tended to perform CWB when participants perceived that perceived supervisor and organizational support were at lower levels. Based on the research by Jacobs et al. (2014), it can also be interpreted that perceived supervisor and organiza- tional support play more roles in explaining CWB, rather than justice perception factor.

The authors argue that perceived supervisor and organizational support can be combined into a concept called Quality of Work Life (QWL). Brunault et al. (2014) suggested that perceived organizational support is associated with QWL. Similarly, Dhar (2012) stated that improving the QWL is synonymous with increasing perceived organizational support. Kottke and Sharafinski (1988) formulated the concept of supervisory support as an operational concept of organizational support. In the context of QWL, supervisors play a role in activities aimed at increasing QWL (Walton, 1980). Based on the relationships between the concepts of perceived supervisor, organizational support, and QWL, the concept of perceived supervisor and organizational support should be represented by the QWL concept in explaining or predicting CWB.

There have not been a numerous research studies that explain the link between the QWL and CWB, particularly in the police force. Hart, Wearing, and Headey (1994) explained the uniqueness of quality of life (QoL) in police force. In their article, Hart et al. (1994) explained that QoL of police is largely sourced from the quality of work life (QWL) experienced. Although employees and police members have experienced various aspects of QWL in their work activities, QWL of police members is unique. Compared to employees in the workplace in general, QWL of police officers has a uniqueness at least in terms of the security and comfort of working conditions. According to Hart et al. (1994), the police's work environment is often exposed to dangerous and risky situations. Such conditions are the specific stressors for the police, which are most likely not experienced by employees outside the police service.

QWL is often perceived by police officers as a stressor, which can trigger CWB. Smoktunowicz, Baka, Cieslak, Nichols, Benight, and Luszczynska (2015) explained that CWB of police officers is predicted by job demands. The higher number of job demands and job control, without social support, is related to burnout experienced by the police. CWB by the members of police force are responses to the stressors (job demands and job control) experienced by the police. Meanwhile social support, in QWL concept, is the operationalization of supervisory and co-worker aspects.

Further research is needed to test the relationship between QWL aspects and CWB. Mazzola and Kessler (2012) have explained that CWB is negatively related to quality of life. However, there has yet to be 
an explanation of the relationship between quality of work life (QWL) and CWB (particularly organizational CWB [CWB-O] and interpersonal CWB [CWBI]. Additionally, the relationships between QWL aspects and CWB dimensions have not yet explained.

Based on the previous literature, the authors proposed a quality of work life (QWL) variable to explain CWB. There were several purposes of study: to describe various (potential) types of counterproductive behavior (CWB) committed by the members of police force; to describe various aspects of quality of work life (QWL) among the members of police force; and to test the role of quality of work life (QWL) as a CWB predictor. The benefits of this study, in addition to being used to explain/predict CWB based on the QWL concept, were also providing an insight into QWL that can be used by the POLRI organization to formulate programs for police personnel. By revealing the significant aspects of QWL in explaining CWB among the members of police force, this study was expected to be the basis of policy/intervention program formulation for the POLRI organization. The efforts to reduce CWB based on research were: creating policies (regulations) that prevent CWB (Boye \& Jones, 1997); organizational restructuring that lead to team work (organic structure; Kessler, 2007); treating employees fairly (interactional/justice policy; Chang \& Smithikrai, 2010); providing supervisory support to subordinates (social support from supervisor; Sakurai \& Jex, 2012); reducing job stressors (Brown, 2012); providing organizational support (Jacobs, Belschak, \& Hartog, 2014); and providing a constructive feedback to those who commit CWB (Suyasa, 2015).

\section{Counterproductive Work Behavior (CWB)}

CWB is considered as behavior that is inconsistent with norms/rules of an organization or as deviant workplace behavior that is potentially harmful to individuals and organizations (Robinson \& Bennett, 1995). The behavior of CWB denotes actions that are illegitimate or against the interests of an organization (Sackett, 2002). CWB is predictable work behavior which is based on the frustration-aggression model (Fox \& Spector, 1999) or based on the emotion-centered model (Fox \& Spector, 2002). According to Fox and Spector (1999; 2002), CWB is defined as work behavior triggered by negative emotions.

The authors posit that in explaining CWB, definitions by Robinson and Bennett (1995) and Sackett (2002), are objective, clear, focused on observed be- havior, and do not rule out that CWB can be explained by models/theories other than frustration-aggression or emotion-centered models. Some studies explain that CWB is not due to frustration-aggression, but because of a lack of closeness to the social environment (based on social control models of deviance, Hirschi, 1969; as cited in Bennett \& Robinson, 2000); the influence of learning on social situations (based on social learning theory, Bandura, as cited in Kwok, Au, \& Ho, 2005, Smithikrai, 2008), or it is based on social exchange theory (Thibaut \& Kelley, as cited in Sakurai \& Jex, 2012).

According to Bennett and Robinson (2000), counterproductive work behavior can be classified into two types: behaviors that are potentially harmful to individual or organizational members (interpersonal deviance or interpersonal counterproductive work behavior [CWB-I]) and behaviors that are potentially harmful to an organization (organizational deviance or organizational counterproductive work behavior [CWB-O]). Both types of behaviors are the results of factor analysis toward the typological concept of deviant workplace behavior formulated by Robinson and Bennett (1995), namely: (a) political deviance (minor-interpersonal deviance); (b) personal aggression (serious-interpersonal deviance); (c) production deviance (minor-organizational deviance); and (d) property deviance (serious-organizational deviance).

Behavior indicators for CWB-I include: being nasty to a fellow worker, starting an argument with someone at work, being verbally abusive to a co-worker; playing a practical joke on someone at work; failing to help a co-worker. Behavioral indicators for CWB$\mathrm{O}$ include: stealing something from work, cheating on the employer; wasting work time or daydreaming rather than doing work; complaining about insignificant things at work; purposely coming to work or back from lunch breaks late; purposely ignoring the supervisor; staying home from work and using sickness as a the reason.

\section{Quality of Work Life (QWL)}

A numerous studies on QWL are generally aimed at improving organizational performance (Katzell, 1983; Lawler, 1982). To date, there is no a universally accepted, a single definition of the QWL (as cited in Hammer, \& Zimmerman, 2011). However, from a variety of definitions, QWL is generally defined as an evaluation made by employees/individuals on their work environment based on their experiences, 
satisfaction, opportunity to participate in a decisionmaking, and based on their relationships with coworkers, or their psychological well-being.

Walton (1980) stated that the concept of QWL is based on aspects such as: adequacy and fairness of compensation, security in working environment, appropriateness of rights/opportunities granted to employees, capacity building for employees, opportunities for a career development, good relationships between employees in the workplace, balancing between family and work life, upper management's attention to employees' welfare, opportunities to channel aspirations, and assessment on various supportive work characteristics (such as a variety of skills required, task clarity, task significance, autonomy, and feedback).

\section{The Role of QWL as a Predictor of CWB based on Social Exchange Theory}

Based on Social Exchange Theory (SET; Homans, 1958; Thibaut \& Kelley, 1959), employee behavior is based on a perceived obligation arising from reciprocal relationships between two parties. In this case, an organization is the first party and an employee is the second party. A sense of responsibility held by all parties arise from the provision of support/ material resources or affective support/trust flowing from the first party to the second party (and vise versa). Sakurai and Jex (2012) used SET to explain CWB. In their study, they explain that the lower the support from superiors (in terms of attention, empathy, appreciation, and information), the higher the employees' tendency to show CWB.

Despite using SET to explain CWB, Sakurai and Jex's (2012) study is limited to civil servants (nonpolice staff). Within the scope of police officers, Mc Carthy, Trougakos, and Cheng (2016) used SET to explain the performance of police personnel. Mc Carthy et al. (2016) explained that the performance of police personnel is considered good, even if the police officers are emotionally exhausted and if the relationships between police officers and their superiors are well established. The better the relationships between police officers and their superiors, the more likely that the police officers feel a sense of responsibility for not committing CWB.

Within the scope of police personnel, CWB may include a violation of norms/rules, or doing things that are potentially harmful to (decrease the reputation of) the police organization. The members of police are likely to engage CWB, either CWB-I (e.g., saying things that hurt the feelings of co-workers, playing a joke on employers/colleagues, or showing negative feelings to superiors/co-workers in performing tasks); or CWB-O (e.g., wasting working time, complaining about things at work, arriving late, stalling, faking illness to avoid work).

CWB conducted by the members of police force can be explained by reciprocal relationships between both parties (SET). In this case, the police organization (as the first party) and members of police force (as a second party). The members of police will have a sense of responsibility for displaying appropriate behavior in accordance to the prevailing norms/ rules, in a sense that police members will not conduct CWB when the police organization provides them with resources/support; either material support or social support in the form of affection/trust. Researchers argue that the support/organizational resources of the police (the first party) can be explained by the QWL concept.

In the QWL concept, material supports include salary/benefits, funding support or training opportunities (personal development), career promotion opportunities, and adequate working environment facilities received by the members of police force (working condition). Meanwhile, social support may include a good relationship with fellow members of police (co-worker), adequate time for individual/family life (a balance of work and family), and a good relationship with supervisors (supervisory).

The various aspects of QWL received by police members will be returned to the organization in the form of effort/performance (perceived obligation), by not displaying CWB. The behavior of CWB displayed by the members of police force is indicative of a lack of a sense of responsibility (perceived obligation). The more positive QWL that employees receive, the more positive their performances, or the lower their CWB. Based on the above framework, the hypotheses were formulated as follows:

H1: Quality of work life would negatively affect counterproductive work behavior. The better the quality of work life (QWL), the lower the counterproductive work behavior (CWB).

\section{Methods}

\section{Participants}

All participants were given informed consent and were informed that their participation was voluntary. 
In this study, the authors planned to collect data from around 500 police force members. However, due to limitations in the field, only 305 police force members were recruited. The age of participants ranged from $18-58$ years $(M=27.42 ; S D=8.85)$. Most participants were males (261 or $85.60 \%$ ), the remaining were females (44 or $14.44 \%$ ). The task force was mostly distributed in the Sabhara unit (111 participants, or $36.29 \%$ ), with the duration of duties of $1-37$ years $(M=8.73 ; S D=8.27)$.

\section{Measure}

Counterproductive work behavior (CWB). CWB measurements were performed on a self-report basis, using the adapted Workplace Deviance measurement scale (Bennett \& Robinson, 2000). CWB-I was measured using 21 items. Examples of the items were "I like to play mean pranks on others"; "I like to make fun of other people"; "In the workplace, I express my feelings of resentment/anger toward others". Higher scores indicate that participants are more likely to make pranks on others, to make fun of other people, and to express feelings of resentment/anger toward others at work. The internal consistency of the 21-item CWB-I measure was good $(\alpha=.96)$.

CWB-O was measured using 27 items. Example of the items were: "I set aside time on the job, to do my personal business."; "I use my work time for less productive activities (talking to my colleagues about things outside my job)"; "I postpone tasks that are urgent". Higher CWB-O scores indicate that participants take their time off to do personal business, to discuss things outside work, and to postpone urgent tasks. The internal consistency of the CWB-O measure was good $(\alpha=.97)$.

The process of administering the CWB measure was based on the frequency rating format. According to Dalal (2005), the measurement of CWB based on frequency rating would make individuals focus on their behavior and thus, provide better discriminant validity evidence than agreement rating. Measuring CWB based on agreement rating has a lower chance on making an individual focus on his/ her behavior, but rather focusing on his/her attitudes or thoughts of CWB based on his/her belief and normative considerations (Dalal, 2005). In CWB measurements based on frequency rating, participants were required to give a cross-mark in accordance with their intensity of CWB in the last 30 days. If participants give a cross to the number "1" on a par- ticular item number, then the participants state that in the last 30 days "they have done CWB once", which is listed on the line/number of the item, and this continues to the option number "5". If participants cross the number " 0 " on a particular item number, then the participants state that they have "never" done CWB.

Quality of work life (QWL). The quality of work life measure used in this study refers to aspects of the quality of work life according to Walton and five sub-dimensions of Hackman and Oldham (Rostiana, Zamralita, \& Suyasa, 2015). These aspects include job characteristics, social relevance of employer, co-worker, pay and benefit, personal development, balance of work and family, promotion, safe and healthy working condition, supervisory, and work culture. For each item, the participants were required to state their agreement on a 5-point rating scale, which were: Brk = very bad; Krng = bad; Ckp $=$ enough; Baik = good; Istmw $=$ excellent.

The first aspect of quality of work life is job characteristic. Job characteristic is defined as a freedom in making decisions, performance appraisal systems, job clarity and responsibilities in the job, as well as the opportunity to use various skills at work. The higher the job characteristic scores, the more participants judge that the organization is better at giving freedom in making decisions, having a clear job appraisal system, having clearer tasks and responsibilities in work, and having a better opportunity to use their skills at work. This aspect has seven indicators. The examples of job characteristic items are: "Freedom in making decisions" and "Clarity of tasks and responsibilities in work". The internal consistency of this aspect was .841 .

The second aspect is social relevance of employer, which means a company's attention to the condition of a wider community around the office, company's efforts to meet customer expectations, as well as company's efforts to produce goods, taking into account the health and safety of customers. The higher the social relevance scores indicate that participants view the company as paying more attention to the condition of community around the office, showing better efforts to meet customer expectations, and to produce goods, taking into account the health and safety of customers. This aspect has five indicators. Examples of social relevance of employer items are: "Attention of the institution/company to the condition of the community around the office" and "Institutional/corporate efforts to produce goods/services, taking into account the health/ 
safety of customers". The internal consistency of this aspect was .830 .

The third aspect is co-worker, which means the availability of social support, social relationships, and communication among co-workers. Higher co-worker scores indicate that participants evaluate higher levels of social support, social relationships, and communication among co-workers. This aspect has three indicators. Examples of co-worker items are: "Social support from co-workers" and "Communication among co-workers". The internal consistency of this aspect was .683 .

The fourth aspect is personal development, which means opportunities to continue education (school) while still working, opportunities to learn special skills (opportunity to attend trainings), opportunities to apply own skills/knowledge, as well as opportunities for self-development. Higher scores of personal development indicate that participants evaluate that the company is better at giving the opportunity to continue education (school) while still working, the opportunity to explore certain skills (training opportunities), the opportunity to apply owned skills/knowledge, and the opportunity for self-development. This aspect has four indicators. Examples of personal development items are: "The opportunity to experience certain skills (training opportunities)" and "The opportunity to apply the skills/knowledge they have". The internal consistency of this aspect was .659.

The fifth aspect of quality of work life is pay and benefits, which means the presence of funds for recreation, facilities/health insurance, monthly income, and pension fund programs. The higher the pay and benefit scores, the more participants judge that the company is better in providing funds for recreation, facilities/health insurance, having better monthly income, and pension fund program. This aspect has five indicators. Examples of pay and benefit items are: "Health / Benefit Facility" and "Income per month". The internal consistency of this aspect was .827 .

The sixth aspect is balance of work and family, which means the presence of a company's support in solving family problems, providing opportunities to work on hobbies outside of work and resolving domestic affairs/duties, and the availability of time for their families. The higher the balance of work and family scores, the more participants consider that the company is better at providing support to participants in resolving family issues, providing more opportunities to work on hobbies outside of work and to finish household tasks, and increasing the availability of time for participants for their families. This aspect has four indicators. Examples of balance of work and family items are: "The support from the company to resolve family issues" and "Opportunities to complete domestic work/duties". The internal consistency of this aspect was .656 .

The seventh aspect is promotion, which means that there are clarity of career improvement mechanism, career opportunity development, and a reward system given to workers according to performance. The higher the scores of promotion, the more participants consider that there is clarity of career improvement mechanism, more career development opportunities, and a good service system to participants based on their performance. This aspect has three indicators. Examples of promotion items are: "Clarity of career improvement mechanism" and "Reward system for workers based on their performance". The internal consistency of this aspect was .751 .

The eighth aspect is safe and healthy working condition, which means that there are security and health facilities in the working environment, the presence of information technology facilities (computers, signal, internet network), as well as a comfortable workplace. Higher scores in this aspect indicate that participants evaluate their company is better at providing security and health facilities in the working environment, providing information technology facilities (computers, signal, internet network), and providing comfort in the workplace. This aspect has three indicators. Examples of safe and healthy working condition items are: "Information technology facilities (computer, signal, internet network)" and "Workplace convenience". The internal consistency of this aspect was .650 .

The ninth aspect is supervisory, which means attention from a direct supervisor to the personal problems of subordinates, work examples set by a direct supervisor, communication a direct supervisor with subordinates, ability of a direct supervisor to direct subordinates, and consistency of a direct supervisor in implementing regulations. Higher supervisory scores mean that participants feel their direct supervisor is concerned about participants' personal problems, sets a better work example, is more capable to direct participants, and is more consistent in implementing regulations. This aspect has five positive indicators. Examples of supervisory items are: "The ability of direct supervisor in directing subordinates" and "Communication of direct supervisor with subordinates". The internal consistency of this aspect was .810. 
The tenth aspect is work culture, which means the availability of culture (value) of regularity and its implementation in work, the implementation of mission of a company, the cultivation of creativity and prioritization of work achievements. Higher scores in work culture correspond with participants' increasingly positive view on their company's culture (value) of regularity and its implementation in work, the implementation of mission of the company, and the cultivation of creativity and prioritization of work achievements. This aspect has eight indicators. Example items of this aspect are: "Culture (value) re- gularity/discipline in work" and "Image of work-place/work institution". The internal consistency of this aspect was .757.

\section{Results}

\section{Description of Counterproductive Work Behavior}

To illustrate counterproductive behavior of participants, the authors used descriptive statistical me-

Table 1

Descriptions of Counterproductive Work Behavior Conducted by Participants

\begin{tabular}{|c|c|c|c|c|c|}
\hline No & Types of Counterproductive Behavior & Min. & Max. & Average & $S D$ \\
\hline & Interpersonal Counterproductive Behavior & 1.00 & 4.05 & 1.52 & 0.71 \\
\hline $1 \mathrm{a}$ & Making fun of supervisor or co-worker. & 1.00 & 5.00 & 1.65 & 0.88 \\
\hline $1 \mathrm{~b}$ & $\begin{array}{l}\text { Telling inappropriate (embarrassing) stories to others about supervisor or co- } \\
\text { worker. }\end{array}$ & 1.00 & 5.00 & 1.52 & 0.86 \\
\hline $2 \mathrm{a}$ & Disliking certain supervisor or co-worker. & 1.00 & 4.50 & 1.40 & 0.74 \\
\hline $3 a$ & Saying something that could offend supervisor or co-worker. & 1.00 & 5.00 & 1.54 & 0.81 \\
\hline $3 \mathrm{~b}$ & Behaving (talking) rudely to supervisor or co-worker. & 1.00 & 5.00 & 1.48 & 0.88 \\
\hline $3 \mathrm{c}$ & Making inappropriate comments in the workplace. & 1.00 & 5.00 & 1.48 & 0.92 \\
\hline 4 & Expressing resentment/anger to supervisor or co-worker in the workplace. & 1.00 & 4.50 & 1.53 & 0.83 \\
\hline 5 & Avoiding supervisor or co-worker on the basis of race/ethnicity/place of origin. & 1.00 & 4.24 & 1.40 & 0.78 \\
\hline \multirow[t]{2}{*}{6} & Playing a mean prank on supervisor or co-worker. & 1.00 & 5.00 & 1.83 & 1.01 \\
\hline & Organizational Counterproductive Behavior & 1.00 & 4.07 & 1.59 & 0.71 \\
\hline $7 \mathrm{a}$ & $\begin{array}{l}\text { Using time at work to do unproductive activities (talking to co-worker about } \\
\text { things unrelated to the job). }\end{array}$ & 1.00 & 5.00 & 1.79 & 1.11 \\
\hline $7 \mathrm{~b}$ & Extending regular break times. & 1.00 & 5.00 & 1.73 & 0.90 \\
\hline $7 \mathrm{c}$ & late without notifying supervisor or co-worker. & 1.00 & 5.00 & 1.55 & 0.96 \\
\hline $7 \mathrm{~d}$ & ks that should be done. & 1.00 & 5.00 & 1.75 & 1.11 \\
\hline $7 \mathrm{e}$ & Not & 1.00 & 5.00 & 1.61 & 1.00 \\
\hline $7 \mathrm{f}$ & Goin & 1.00 & 5.00 & 1.61 & 0.96 \\
\hline $7 \mathrm{~g}$ & things unrelated to the job. & 1.00 & 5.00 & 1.65 & 0.83 \\
\hline 8 & $\begin{array}{l}\text { Delegating tasks to supervisor or co-worker that are supposed to be my } \\
\text { responsibility. }\end{array}$ & 1.00 & 4.50 & 1.48 & 0.82 \\
\hline 9 & Saying sick to supervisor o & 1.00 & 5.00 & 1.49 & 0.96 \\
\hline $9 \mathrm{a}$ & $\begin{array}{l}\text { Taking home office equipments (paper, pens, etc.) without notifying } \\
\text { supervisor or co-worker. }\end{array}$ & 1.00 & 5.00 & 1.38 & 0.82 \\
\hline $9 b$ & $\begin{array}{l}\text { Manipulating receipts (that is not correct/valid) to get reimbursement from the } \\
\text { company. }\end{array}$ & 1.00 & 5.00 & 1.37 & 0.80 \\
\hline $9 \mathrm{c}$ & Trying to get tips/additional pay/overtime compensation in doing tasks. & 1.00 & 4.50 & 1.73 & 0.84 \\
\hline 9d & nal activities. & 1.00 & 5.00 & 1.90 & 1.01 \\
\hline 10 & pervisor. & 1.00 & 4.75 & 1.56 & 0.78 \\
\hline 11 & Leavi & 1.00 & 5.00 & 1.61 & 0.91 \\
\hline $12 \mathrm{a}$ & $\begin{array}{l}\text { Discussing confidential information not with supervisor (or any authorized } \\
\text { figures). }\end{array}$ & 1.00 & 5.00 & 1.45 & 0.86 \\
\hline & Settin & 1.00 & 5.00 & 1.43 & 0.87 \\
\hline $12 \mathrm{c}$ & Telling others numerous bad things that happened in the workplace & 1.00 & 5.00 & 1.48 & 0.89 \\
\hline
\end{tabular}

Note. $\quad$ Range of measurement $0-5 ; 0=$ has never done the behavior in question; $1=$ has done the behavior in question once;

$2=$ has done the behavior in question twice; etc. up to $5=$ has done the behavior in question up to five times within a month. 
thods. Based on the results of 305 participants, a description of the counterproductive behavior is shown in Table 1 .

Table 1 showed, it is apparent that participants conducted two types of counterproductive behaviors, which were: (a) interpersonal counterproductive behavior (CWB-I), with an average score of 1.52; and (b) organizational counterproductive behavior (CWB$\mathrm{O})$, with an average score of 1.59 . This means that participants conducted 1-2 counterproductive behaviors. Organizational counterproductive behavior seemed to be done slightly more (.07 points) compared to interpersonal counterproductive behavior.

Based on Table 1, it appears that there were four types of interpersonal counterproductive work behaviors that could be classified as frequently performed by participants (score $>M=1.52$ ). These included: (a) Playing a prank on supervisor or co-worker (Item 6); (b) Making fun of supervisor or co-worker (Item 1a); (c) Saying something that could offend supervisor or co-worker (Item 3c); and (d) Expressing resentment/anger to supervisor or co-worker in the workplace (Item 4).

Meanwhile, there were nine types of organizational counterproductive work behaviors (score $>M=$ 1.59) as seen in Table 1. They were: (a) Setting aside time at work to do personal activities (Item 9d); (b) using time at work to do unproductive activities (talking to co-worker about things unrelated to the job; (Item 7a); (c) Delaying tasks that should be done (Item 7d); (d) Extending regular break times (Item 7b); (e) Trying to get tips/additional pay/overtime compensation in doing tasks (Item 9c); (f) Using telephone/Internet for things unrelated to work (Item 7g); (g) Not being motivated to do the job (Item 7e); (h) Going home earlier without notifying supervisor (Item 7f); and (i) Leaving desk unclean or untidy (Item 11).

\section{Description of Quality of Work Life (QWL)}

To describe participants' QWL, the authors used descriptive statisical methods. Based on data from 305 participants, their QWL is presented in Table 2.

Table 2 revealed, there were five QWL aspects that were rated highly by participants. These were (from higher to the lower scores): (a) Relationship with co-worker (Co-worker); (b) Work culture (Constitutionalism); (c) Relationship with Supervisor (Supervisory); (d) Condition/Work facilities (Working Con-dition); and (e) Social relevance of employer.

\section{The Role of Quality of Work Life (QWL) as a Predictor of Counterproductive Work Behavior (CWB)}

In this section, the authors will explain the role of QWL as a predictor of interpersonal CWB (CWB-I) and the role of QWL as a predictor of organizational CWB (CWB-O).

\section{The Role of QWL as a Predictor of CWB-I}

For testing the role of QWL on CWB-I, PLS software (version 3.2.3) was used. Results yielded two outputs, which were: (a) Figure/image on the role of QWL component to CWB-I (Figure 1); and (b) Statistical coefficients based on the bootstrapping method (Table 3).

Table 2

Descriptions of Participants' Quality of Work Life (OWL)

\begin{tabular}{llcccc}
\hline No & Aspect of Quality Work Life & Min. & Max. & Average & SD \\
\hline & Quality of Work Life (Overall) & 1.07 & 5.00 & 3.44 & 0.613 \\
& & & & & \\
1 & Satisfaction with Job Characteristic (Job characteristic) & 1.00 & 5.00 & 3.39 & 0.702 \\
2 & Social Relevance of Employer & 1.00 & 5.00 & 3.46 & 0.664 \\
3 & Relationships with Co-workers (Co-Worker) & 1.00 & 5.00 & 3.66 & 0.733 \\
4 & Opportunities for self development (Personal Development) & 1.00 & 5.00 & 3.44 & 0.719 \\
5 & Salary and allowance (Pay and Benefit) & 1.00 & 5.00 & 3.32 & 0.692 \\
6 & Balance of work and personal life (Work Life Balance) & 1.00 & 5.00 & 3.14 & 0.772 \\
7 & Promoting responsibilities (Promotion) & 1.00 & 5.00 & 3.39 & 0.757 \\
8 & Condition/work facilities (Working Condition) & 1.00 & 5.00 & 3.47 & 0.768 \\
9 & Relationship with Supervisor (Supervisory) & 1.00 & 5.00 & 3.49 & 0.713 \\
10 & Work Culture (Constitutionalism) & 1.25 & 5.00 & 3.56 & 0.631 \\
\hline Note. & Range of measurement 1 - 5. 1 = Very Bad; 2 = Bad; 3 = Average; 4= Good; 5= Excellent. & &
\end{tabular}


Table 3

Statistical Results of the Role of QWL on CWB-I Based on the Bootstrapping Method

\begin{tabular}{clrcc}
\hline No & Aspect of Quality Work Life & $\boldsymbol{r}$ & $\boldsymbol{T}$ & $\boldsymbol{p}$ \\
\hline 1 & Job characteristic & 0.086 & 0.836 & 0.403 \\
2 & Social Relevance of Employer & -0.028 & 0.299 & 0.765 \\
3 & Relationships with Co-workers (Co-Worker) & -0.195 & 2.039 & 0.041 \\
4 & Opportunities for self development (Personal Development) & 0.095 & 1.064 & 0.287 \\
5 & Salary and allowance (Pay and Benefit) & 0.080 & 0.850 & 0.395 \\
6 & Balance of work and personal life (Work Life Balance) & 0.184 & 2.812 & 0.005 \\
7 & Promoting responsibilities (Promotion) & -0.200 & 1.958 & 0.050 \\
8 & Condition/work facilities (Working Condition) & 0.085 & 0.709 & 0.479 \\
9 & Relationship with Supervisor (Supervisory) & -0.317 & 3.814 & 0.000 \\
10 & Work Culture (Constitutionalism) & -0.260 & 2.186 & 0.029 \\
\hline
\end{tabular}

Table 4

Statistical Results of the Role of QWL on CWB-O Based on the Bootstrapping Method

\begin{tabular}{llrrr}
\hline No & Aspect of Quality Work Life & $\boldsymbol{r}$ & $\boldsymbol{T}$ & $\boldsymbol{p}$ \\
\hline 1 & Job characteristic & -0.175 & 1.718 & 0.086 \\
2 & Social Relevance of Employer & 0.055 & 0.579 & 0.563 \\
3 & Relationships with Co-workers (Co-Worker) & -0.114 & 1.451 & 0.147 \\
4 & Opportunities for self development (Personal Development) & -0.016 & 0.179 & 0.858 \\
5 & Salary and allowance (Pay and Benefit) & 0.035 & 0.422 & 0.673 \\
6 & Balance of work and personal life (Work Life Balance) & 0.041 & 0.561 & 0.575 \\
7 & Promoting responsibilities (Promotion) & -0.077 & 0.756 & 0.450 \\
8 & Condition/work facilities (Working Condition) & 0.077 & 0.780 & 0.435 \\
9 & Relationship with Supervisor (Supervisory) & $\mathbf{- 0 . 1 9 8}$ & $\mathbf{2 . 3 3 9}$ & $\mathbf{0 . 0 1 9}$ \\
10 & Work Culture (Constitutionalism) & -0.207 & 1.624 & 0.104 \\
\hline
\end{tabular}

Based on the analyses of QWL's role on CWB-I, there were five aspects of QWL that had an impact on CWB-I, which were the aspects of: Supervisory $(b=-0.317, p<.01)$, Work Life Balance $(b=0.184$, $p<.01)$, Constitutionalism $(b=-0.264, p<.05)$, Co-worker $(b=-0.195, p<.05)$, and Promotion $(b$ $=-0.200, p<.05$ ). Four aspects of QWL (Supevisory, Consitutionalism, Co-Worker, and Promotion) had a negative impact on CWB-I, meaning that the more positive the QWL (i.e., the better relationship with supervisor, the more consistent rules/norms in the workplace, the better relationship with coworkers, and clearer mechanism of career promotion/reward system), the lower/the more negative the CWBI (i.e., the more likely that participants did not make fun of supervisor, they did not say anything that could offend co-workers, and they were able to manage their feelings of resentment/anger toward their supervisor/co-workers).

Out of the four significant aspects of QWL, one of them (Work Life Balance [WLB]) showed a positive correlation with CWB-I $(b=0.184, p<.01)$. This means that the lower the WLB (i.e., the less time for participants to work on their hobbies out-side of work, less time for participants to spend time with their family), the lower their CWB-I (i.e., the less time for participants to tell jokes, less chance of saying things that could offend others, and less likelihood of feeling resentful/angry).

\section{The Role of QWL as a Predictor of CWB-O}

Testing the impact of QWL on CWB-O was also performed using PLS software (version 3.2.3). The results showed two outputs, which were: (a) Image of the role of QWL's component on CWB-O (Figure 2); and (b) Statistical coefficients based on the bootstrapping method (Table 4).

Based on the analyses of the role of QWL on CWB-O, only one aspect of QWL had a significant impact, which was supervisory $(b=-0.198, p<.01)$. This aspect had a negative impact on CWB-O, meaning that the higher levels of QWL (i.e., the more capable a supervisor in managing his/her subordinates, the more attentive he/she to subordinates' problems, the more capable he/she to set an example, 


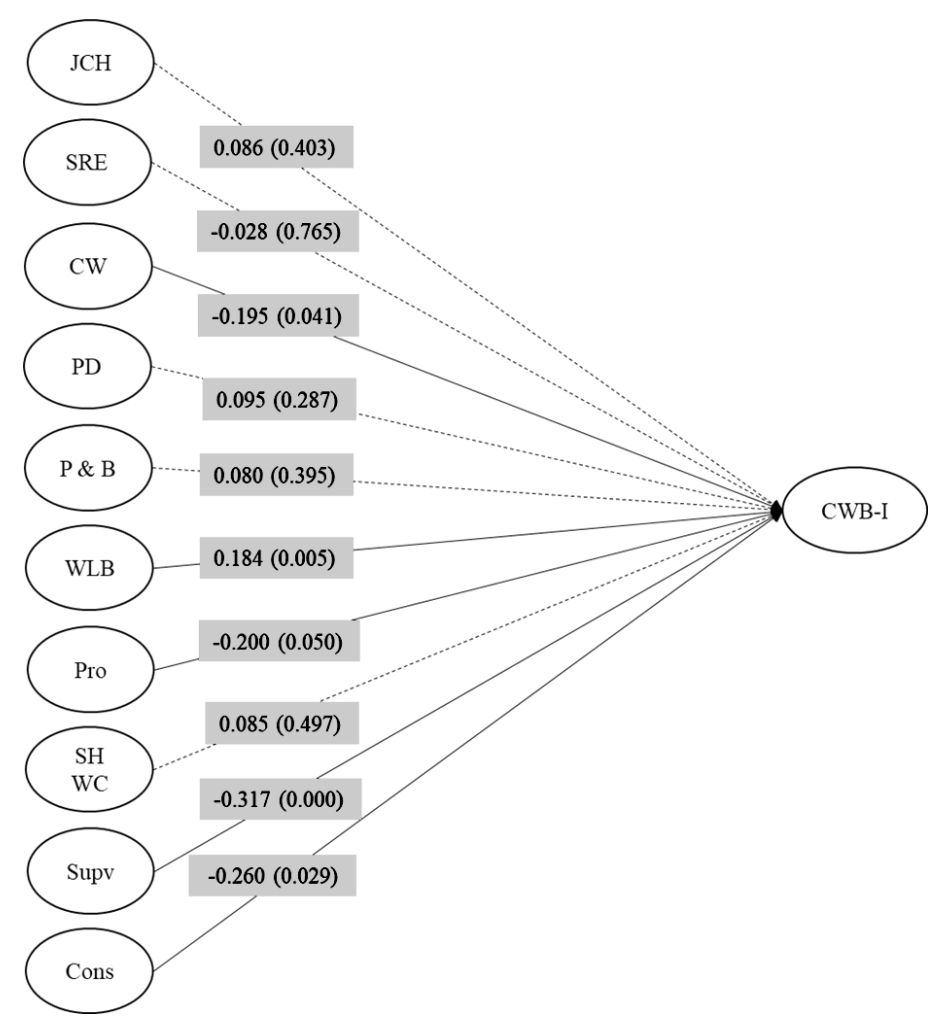

Figure 1. Role of QWL on CWB-I.

to have better communication skills, and to be more consistent with rules and regulation), the lower the levels of CWB-O (i.e., participants did not set aside their worktime to do personal activities, they did not postpone their work, they did not try to get tips/extra money/overtime compensation, they did not use Internet/telephone for things outside of work, they did not go home earlier without notifying supervisor).

Based on the analyses of the role of QWL on CWB using the bootstrapping method with PLS software (version 3.2.3), it revealed that among the various aspects of QWL, the supervisory aspect was consistent in predicting CWB, either CWB-I $(b=-$ $0.317, p=.000)$, or CWB-O $(b=-0.198, p=.019)$. The higher the supervisory scores, the lower the CWB scores, both the CWB-I and CWB-O scores. This means that the more positive the perception of participants to their supervisor (i.e., the superior was perceived to be able to provide direction, to care about the personal problems of subordinates, to able to set an example in work, to have a good communication with subordinates, and was considered consistent in implementing rules), the lower the intensity of counterproductive work behavior (CWB-I \& CWB-O) performed by participants.

\section{Discussion}

Although it seems that the police force represents a serious and hierarchical organization, there is an indication that police force members like to make fun of their supervisors/co-workers. Results showed that mischievous behavior (pulling a prank) on others/ supervisors/co-workers was categorized as the most frequent counterproductive work behavior (CWB-I). The second most frequent CWB-I was making fun of supervisors/coworkers, followed by saying things that could offend supervisor/coworkers. The three behaviors could all be done simultaneously, for example when doing security work or during patrol periods.

Despite being done regularly, the frequency of three aforementioned behaviors was still low. The authors assume that such mischievous behavior could be considered as a stress-relief mechanism (Tucker, Sinclair, Mohr, Adler, Thomas, \& Salvi, 2009), or as a symbol of friendship/relationship between a supervisor and a subordinate. A layman's opinion may suggest that playing a joke on supervisors/co-workers and saying something that might offend them are normal and sometimes necessary. However, based on the definition of counter-productive behavi- 


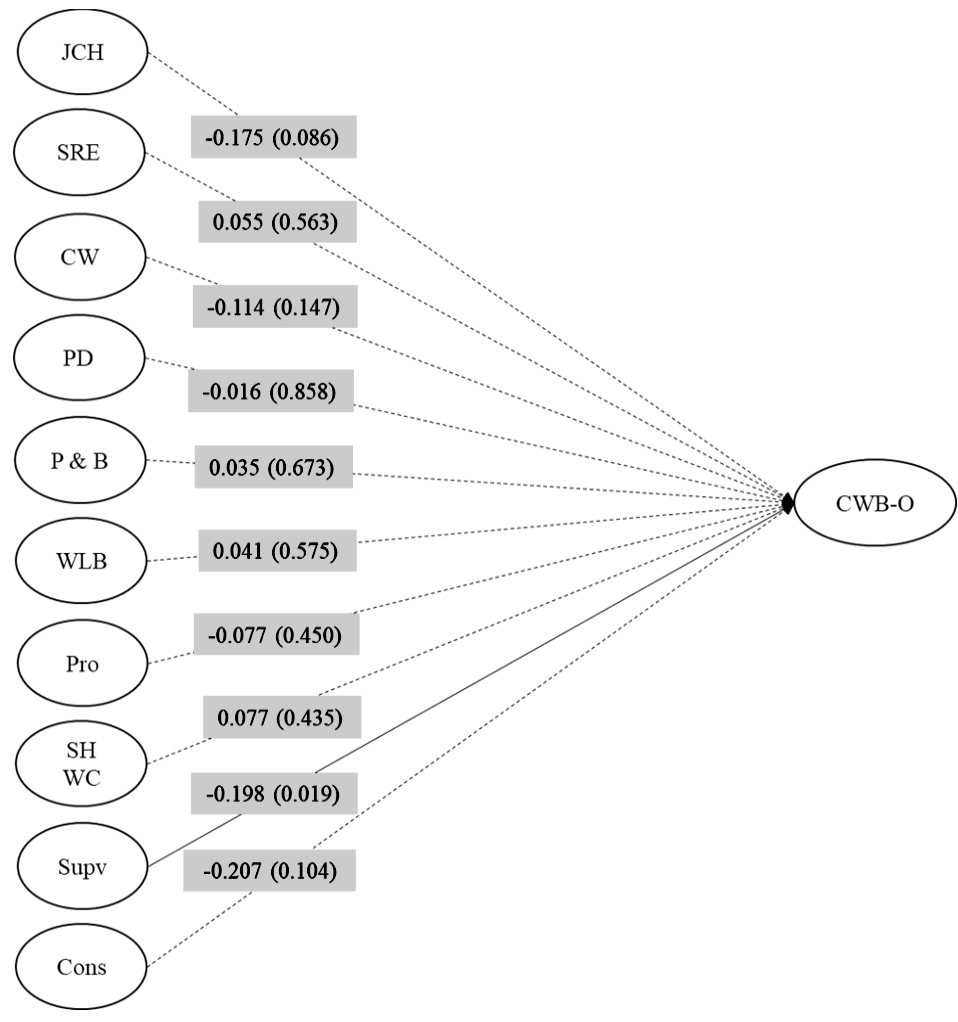

Figure 2. Role of QWL on CWB-O.

or, i.e., behavior that is not in accordance with norms/ rules (formal/informal), the authors still consider the above behavior as CWB.

The authors think that the three aforementioned behaviors could be considered as violating the behavioral norms stated on the Kapolri Regulation Number 7 Year 2006 about the Professional Code of Ethics of POLRI, and these behaviors potentially harm the organization and/or POLRI. The articles and paragraphs in the Kapolri Regulation Number 7 Year 2006 concerning the Professional Code of Ethics of POLRI may be violated due to these behaviors, for example: (a) Article 5 (Item c) stating that POLRI members should treat fellow members as dignified subjects; (b) Article 6 stating that POLRI members, in exercising their authority, shall be obliged to observe the norms of decency and morality; (c) Article 8 (Paragraph 1) stating that every member of POLRI is obliged to display a leadership attitude through exemplary behavior and dignity; and (d) Article 9 (Item c) stating that it is the moral duty of a superior or subordinate to show mutual, sincere respect.

Organizational counterproductive work behavior (CWB-O) that was the most frequently done by the police were: setting aside time at work to do personal activities, using time at work to talk about matters unrelated to the job, and postponing tasks that should be done. Such behaviors indirectly violate the Kapolri Regulations Number 7 Year 2006 about the Professional Code of Ethics of POLRI. There is no article in the regulation that specifically states that police force members should not set aside time at work to do personal activities, to use time at work to talk about matters unrelated to the job, or that they should not postpone tasks that need to be done.

If doing personal activities during work and talking to peers about things outside of work do not have the potential to disrupt the completion of tasks, then perhaps it is not urgent to include the prohibition of such behavior to the Professional Code of Ethics of POLRI. However, if the stakeholders (people in the community and POLRI leaders) perceive such behavior as potentially disruptive to the police force's service to the community, then it might be time to consider adding some CWB-O criteria to the Professional Code of Ethics of POLRI.

Results of the hypothesis testing revealed that quality of work life (QWL) had a negative relationship 
with counterproductive work behavior (CWB). This finding supports Mazzola and Kessler (2012) who explain CWB based on general quality of life. The results of this study are in line with Jacobs et al.'s (2014) findings that perceived supervisor and organizational support are factors that could explain CWB; however both perceived supervisor and organizational support are considered as parts of the QWL concept. It seems that the most influential QWL aspect on CWB (both CWB-I and CWB-O) is supervisory. This implies that lower levels of CWB are associated with more monitoring, help, support, and time given from supervisors to employees.

Based on the results of this study, supervisory was the aspect of QWL that was mostly responsible for CWB (both CWB-I and CWB-O). Based on these findings, the authors suggest that POLRI leaders (or supervisors) should apply optimal supervisory to reduce CWB conducted by POLRI subordinates. This can be done by showing concerns about the personal problems of subordinates, keeping a good level of communication, being consistent in implementing rules and setting a good example in implementing discipline/regulations (or being capable to direct subordinates). With optimal supervisory, it is expected that POLRI members (subordinates) will not conduct CWB (i.e., will not play pranks on people, will not make fun of others or supervisors, will not talk about the bad side of supervisors, or will not use work time to talk about unproductive things outside of work).

In particular, for predicting CWB-I, the QWL aspects that played significant roles include: co-worker, promotion, supervisory, constitutionalism, and work life balance. The better the quality of relationships with co-workers (co-worker), the better the quality of the system of assignment/career improvement (promotion), the better the relationship with supervisor (supervisory), the clearer rules in the workplace (constitutionalism), then the lower the intensity of interpersonal counterproductive work behavior (CWB-I). The lower levels of CWB-I indicate that police officers do not talk about negative things of their colleagues/superiors, do not say anything that potentially makes others offended, or do not show bad attitude when working as the member of police force.

Based on social exchange theory, an individual who feels that they have been received kindness from others will feel responsible (perceived obligation) to repay the kindness. Related to the results of this stu$\mathrm{dy}$, the more the members of police feel that they have received the kindness from the POLRI organization, the more likely they will have a sense of responsibility to repay the kindness in the form of good performance (not doing CWB-I). Good relationships with fellow members of police (co-worker), good relationships with a supervisor (supervisor), a clear system of assignment/career progression (promotion), and the implementation of consistent rules (constitutionalism), are the aspects of QWL perceived by the members of police as positive things that they receive. The various benefits received create a sense of responsibility to repay the kindness. The sense of responsibility will continue as long as the police officers perceive that the four aspects of QWL are continuously received (the equilibrium has not yet reached).

Interestingly, among the five aspects of QWL that played a role in predicting CWB-I (i.e., supervisory, constitutionalism, co-worker, promotion, and work life balance), the aspect of work life balance had a positive relationship with CWB. The higher the work life balance (i.e., the more participants have the opportunity to do their hobbies outside of work and the more time they have for their family), the higher the CWB-I performed by participants. Based on Beauregard and Henry's (2009) research, work life balance was positively associated with performance. If CWB is classified as a negative performance concept (Rotundo \& Sackett, 2002), then CWB should be negatively related to work life balance; in other words, the higher levels of work life balance, the higher the performance (the lower the CWB). But the results of this study showed that the higher levels of work life balance, the lower the performance (the higher the CWB). The result that showed a positive correlation between work life balance and CWB raises a question for further research.

Beuregard and Henry (2009) stated that there was not sufficient evidence to show that increasing work life balance (reducing work life conflict) could increase organizational performance. To explain organizational performance based on the increased work life balance, it requires an investigation on further mechanism or inclusion of other variables that play a role as moderating or mediating variables. For example, work life balance is a form of reward given by an organization to its employees (social exchange process) that could reduce turnover, which then results in saving costs, and finally, influences organizational performance. Beauregard (2014) posited the adaptive/maladaptive perfectionism is a moderating variable that can explain the contexts of work 
life balance and CWB.

Based on Beauregard's (2014) study, adaptive perfectionism weakened the relationship between informational justice and CWB; whereas maladaptive perfectionism strengthened the relationship between informational justice and CWB. The authors assume that if adaptive/maladaptive perfectionism functions as a moderating variable in explaining the relationship between work life balance (WLB) and CWB-I, then adaptive perfectionism may weaken the relationship between WLB and CWB-I; whereas maladaptive perfectionism may strengthen the relationship between WLB and CWB-I.

Adaptive/maladaptive perfectionism reflects the amount of attention given to a mistake and the level of doubt/negative thoughts on an actions/activities. The authors think that a positive relationship between work life balance and CWB will be (strongly) present when participants have maladaptive perfectionism (i.e., showing too much attention on mistakes and having a sense of doubt on an action/activity). Participants with maladaptive perfectionism who score high on work life balance might end up finding more problems in his/her private or family life when given more opportunities to work on their own personal or family problems. Thus, when arriving at the workplace, participants will complain or show negative emotions on others in the workplace (i.e., they will conduct CWB-I). For future research, the content of such complaints could be further investigated. The authors assume that the complaint might be about imperfect home/family situations or imperfect work conditions (supervisors/co-workers who do not meet their expectations).

On the other hand, the authors understand that complaining at work or showing negative emotions in the workplace is a coping or stress release mechanism (Tucker et al., 2009). The members of POLRI who have the need to relate/socialize with family members (parent/child/spouse) may feel that they have only limited time to meet their family due to their working demands. In this condition, it is probable that POLRI members show depressed/sad feeling (Bripka Dewi feat Nadya Rafika, March 02, 2015). To relieve stress, POLRI members may com-plain about the conditions they have experienced to their colleagues, make a joke or conduct CWB-I to reduce their distress.

However, this study has limitations. The authors identify at least three shortcomings in this study. First, the authors acknowledge that this study might con-tain a common method variance bias that is likely to affect the results of this study. In subsequent research, it is necessary to consider methods other than self-report to collect CWB (negative performance) and QWL data. Second, in this study there may be particular types of CWB-I and CWB-O uni-que to the police force that have not yet investigated using current measures. Thus, for subsequent research, focus group discussion (FGD) and in-depth interview might be need to modify the measures used. Through FGD and depth interview, it is expected that the particular types of CWB-I and CWB-O could be identified specifically for the police force, other directorates, particularly the directorates that are highly relied upon by the community. Finally, the finding regarding the positive relationship between the QWL aspect; that is, work life balance and CWB-I has not been explained empirically. Further research is needed to identify variables that can explain in which situation that work life balance is positively related to CWB-I and in which situation it is unrelated (negatively related) to CWB (particularly CWB-I).

\section{Conclusion}

Based on this research, the following two points are concluded: (a) There were two types of CWB that were conducted by police officers. The types of CWBI that were frequently conducted by the members of police force were: pulling pranks on others/co-workers, making fun of others, and saying something that could make others offended. The types of CWB$\mathrm{O}$ that were usually conducted by the members of police force were: setting aside time on the job to do personal activities, using time at work to chat with colleagues on matters unrelated to work, and delaying the tasks that were supposed to be done; (b) Based on the results of the hypothesis testing, the quality of work life (QWL) was negatively related to counterproductive work behavior $(\mathrm{CWB})$. The higher the QWL scores, the lower the levels of CWB. The QWL aspect that play a role on both CWB-I and CWB-O was supervisory.

\section{References}

Beauregard, T. A. (2014). Fairness perceptions of work-life balance initiatives: Effects on counterproductive work behaviour. British Journal of Management, 25(4), 772-789. http://dx.doi.org/10.11 11/1467-8551.12052

Beauregard, T. A., \& Henry, L. C. (2009). Making the link between work-life balance practices and organizational performance [Abstract]. Human Re- 
source Management Review, 19(1), 9-22. http://dx. doi.org/10.1016/j.hrmr.2008.09.001

Bennett, R. J., \& Robinson, S. L. (2000). Development of a measure of workplace deviance. Journal of Applied Psychology, 85(3), 349-360. http:// dx.doi.org/10.1037/0021-9010.85.3.349

Boye, M. W., \& Jones, J. W. (1997). Organizational culture and employee counterproductivity. In R. A. Giacalone \& J. Greenberg (Eds.), Antisocial behavior in organizations (pp. 172-184). Thousand Oaks, CA: Sage Publications. Retrieved April 25th, 2012 from https://goo.gl/GJx7v9

Bripka Dewi feat Nadya Rafika (02 Maret 2015). Di situ saya kadang sedih. Eka Gustiwana (Ed.). YouTube video accessed on September 4th, 2016 from https://www.youtube.com/watch?v=wAYQ0ul7O3g

Brown, T. G. (2012). Job stress and counterproductive work behaviors: Does moral identity matter? Seattle Pacific University. ProQuest Dissertations and Theses, 127. Retrieved from http://searc h.proquest.com/docview/ 1074792425?accountid $=17242$. (1074792425).

Brunault, P., Fouquereau, E., Colombat, P., Gillet, N., El-Hage, W., Camus, V., \& Gaillard, P. (2014). Do transactive memory and participative teamwork improve nurses' quality of work life? [Abstract]. Western Journal of Nursing Research, 36(3), 329-345. http://dx.doi.org/10.1177/01939459134 93015

Chang, K., \& Smithikrai, C. (2010). Counterproductive behaviour at work: An investigation into reduction strategies. The International Journal of Human Resource Management, 21(8), 1272-1288. http://dx. doi.org/10.1080/09585192.2010.483852

Dalal, R.S. (2005). A meta-analysis of the relationship between organizational citizenship behavior and counterproductive work behavior. The Journal of Applied Psychology, 90(6), 1241-1255. http://dx. doi.org/10.1037/0021-9010.90.6. 1241

Dhar, R. L. (2012). Employees' perception of organizational support: A qualitative investigation in the Indian information technology (IT) industry. Work: Journal of Prevention, Assessment \& Rehabilitation, 43(2), 211-222.

Erdem, M. (2014). The level of quality of work life to predict work alienation. Kuram ve Uygulamada Eğitim Bilimleri, 14(2), 534-544.

Fox, S., \& Spector, P. E. (1999). A model of work frustration-aggression. Journal of Organizational Behavior, 20(6), 915-931.

Fox, S., \& Spector, P. E. (2002). An emotion-centered model of voluntary work behavior. Some parallels between counterproductive work behavior and organizational citizenship behavior. $\mathrm{Hu}$ man Resource Management Review, 12, 1-24.

Hammer, L. B., \& Zimmerman, K. L. (2011). Quality of work life. In S. Zedeck (Ed.), APA Handbooks in Psychology. APA handbook of industrial and organizational psychology, Vol. 3. Maintaining, expanding, and contracting the organization (pp.399-431). http://dx.doi.org/10.1037/12171-0

Hart, P. M., Wearing, A. J., \& Headey, B. (1994). Perceived quality of life, personality, and work experiences: Construct validation of the policedaily hassles and uplifts scales. Criminal Justice and Behavior, 21(3), 283-311.

Homans, G. C. (1958). Social behavior as exchange. American Journal of Sociology, 63(6), 597606. http://dx.doi.org/10.1086/222355. Retrieved July 15th, 2013 from http://www.jstor.org/disco ver/10.2307/2772990?uid=3738224\&uid=2\&uid $=4 \&$ sid $=21104335124057$

Jacobs, G., Belschak, F. D., \& Hartog, D. N. (2014). (Un)ethical behavior and performance appraisal: The role of affect, support, and organizational justice. Journal of Business Ethics, 121(1), 63-76. http://dx.doi.org/10.1007/s10551-013-1687-1

Katzell, R. A. (1983). Improving quality of work life. American Psychologist, 38(1), 126. http://dx. doi.org/10.1037/0003-066X.38.1.126.a

Kepolisian Republik Indonesia. (n.d.). Visi misi organisasi Kepolisian Republik Indonesia. Retrieved January 25th, 2015 from http://www.polri.go. id/organisasi/op/vm/

Kessler, S. R. (2007). The effects of organizational structure on faculty job performance, job satisfaction, and counterproductive work behavior. Dissertation Abstracts International: Section B: The Sciences and Engineering, 68(4-B), 2697. (UMI No. AAI3260070).

Kottke, J. L., \& Sharafinski, C. E. (1988). Measuring perceived supervisory and organizational support. Educational and Psychological Measurement, 48(4), 1075-1079. http://dx.doi.org/10.11 77/0013164488484024

Kwok, C. K., Au, W. T., \& Ho, J. M. C. (2005). Normative controls and self-reported counterproductive behaviors in the workplace in China. $A p$ plied Psychology: An International Review, 54 (4), 456-475. http://dx.doi.org/10.1111/j.1464-05 97.2005.00220.x

Lawler, E. E. (1982). Strategies for improving the quality of work life. American Psychologist, 37(5), 486-493. http://dx.doi.org/10.1037/0003-066X.37 


\subsection{6}

Marcus, B., \& Schuler, H. (2004). Antecedents of counterproductive behavior at work: A general perspective. Journal of Applied Psychology, 89(4), 647-660. http://dx.doi.org/10.1037/0021-9010.89. 4.647

Mazzola, J. J., \& Kessler, S. R. (2012). Counterproductive work behaviors and their ethical dilemmas: Creating just, respectful, and productive organizations [Abstract]. Sirgy, M. Joseph \& Gorman, C. Allen (Eds.). Work and quality of life: Ethical practices in organizations. International handbooks of quality-of-life. (pp. 157-179). New York, NY, US: Springer Science \& Business Media. http://dx.doi.org/10.1007/ 978-94-007-4059-4_9

McCarthy, J. M., Trougakos, J. P., \& Cheng, B. H. (2016). Are anxious workers less productive workers? It depends on the quality of social exchange. Journal of Applied Psychology, 101(2), 279-291. http://dx. doi.org/10.1037/ap10000044

Munir, S. (Selasa, 30 Desember 2014 - 19:46 WIB). 2014, 9892 Polisi Langgar Disiplin. Retrieved January 25th, 2015 from http://nasional.sindone ws.com/read/944094/14/2014-9892-polisi-langg ar-disiplin-1419943553

Peraturan Kapolri No. 7 Tahun 2006 tentang Kode Etik Profesi POLRI. (n.d.). Retrieved February 14th, 2016, from https://goo.gl/EEFpwm

Peraturan Pemerintah No. 2 Tahun 2003 tentang Disiplin Anggota Kepolisian Negara Republik Indonesia. (2003). Jakarta: Djambatan.

Robinson, S. L., \& Bennett, R. J. (1995) A typology of deviant workplace behaviors: A multidimensional scaling study. Academy of Management Journal, 38, 555-572.

Rostiana, Zamralita, \& Suyasa, P. T. Y. S. (2015). Alat ukur quality of work-life. Lembaga Penelitian dan Publikasi Ilmiah, Universitas Tarumanagara, Jakarta.

Rotundo, M., \& Sackett, P. R. (2002). The relative importance of task, citizenship, and counterproductive performance to global ratings of job performance: A policy-capturing approach. Journal of Applied Psychology, 87(1), 66-80. http://dx. doi.org/10.1037/0021-9010.87.1.66
Sackett, P. R. (2002). The structure of counterproductive work behaviors: Dimensionality and relationships with facets of job performance. International Journal of Selection and Assessment, 10, 5-11.

Sakurai, K., \& Jex, S. M. (2012). Coworker incivility and incivility targets' work effort and counterproductive work behaviors: The moderating role of supervisor social support. Journal of Occupational Health Psychology, 17(2), 150-161. http://dx.doi.org/10.1037/a0027350

Smithikrai, C. (2008). Moderating effect of situational strength on the relationship between personality traits and counterproductive work behaviour. Asian Journal of Social Psychology, 11(4), 253-263. http://dx.doi.org/10.1111/j.1467-839X. 2008.00265.x

Smoktunowicz, E., Baka, L., Cieslak, R., Nichols, C. F., Benight, C. C., \& Luszczynska, A. (2015). Explaining counterproductive work behaviors among police officers: The indirect effects of job demands are mediated by job burnout and moderated by job control and social support. Human Performance, 28(4), 332-350. http://dx.doi.org/1 0.1080/08959285.2015.1021045

Suyasa, P. T. Y. S. (2015). Studi mengenai perilaku kerja kontraproduktif. Pengaruh cara menegur terhadap kesantaian-kerja dan kesalahan kerja (Dissertation). Fakultas Psikologi, Universitas Indonesia.

Thibaut, J. W., \& Kelley, H. H. (1959). The social psychology of groups. New York: Wiley. http:// books.google.co.id/books?id=KDH5Hc9F2AkC $\&$ printsec $=$ front cover $\# \mathrm{v}=$ onepage $\& \mathrm{q} \& \mathrm{f}=$ false

Tucker, J. S., Sinclair, R. R., Mohr, C. D., Adler, A. B., Thomas, J. L., \& Salvi, A. D. (2009). Stress and counterproductive work behavior: Multiple relationships between demands, control, and soldier indiscipline over time. Journal of Occupational Health Psychology, 14(3), 257-271. http:// dx.doi.org/10.1037/a0014951

Undang-Undang Republik Indonesia Nomor 2 Tahun 2002 tentang Kepolisian Negara Republik Indonesia. (2002). Jakarta: Djambatan.

Walton, R. (1980). Quality of work life activities: A research agenda. Professional Psychology, 11(3), 484-493. 